\title{
Mitochondrial processing peptidase activity is controlled by the processing of $\alpha$-MPP during development in Dictyostelium discoideum
}

Correspondence

Tetsuo Ohmachi

tohmachi@cc.hirosaki-u.ac.jp

Received 2 September 2009

Revised 7 December 2009

Accepted 14 December 2009
Koki Nagayama ${ }^{1,2} \dagger$ and Tetsuo Ohmachi ${ }^{2}$

\author{
${ }^{1}$ Science of Bioresources, United Graduate School of Agricultural Sciences, Iwate University, \\ Morioka, Iwate 020-8551, Japan \\ ${ }^{2}$ Department of Biochemistry and Biotechnology, Faculty of Agriculture and Life Science, Hirosaki \\ University, Hirosaki, 036-8561, Japan
}

\begin{abstract}
We investigated the expression of the $\alpha$ subunit of the Dictyostelium mitochondrial processing peptidase (Dd $\alpha$-MPP) during development. Dd $\alpha$-MPP mRNA is expressed the highest levels in vegetatively growing cells and during early development, and is markedly downregulated after $10 \mathrm{~h}$ of development. The Dd $\alpha$-MPP protein is expressed as two forms, designated $\alpha-\mathrm{MPP}_{\mathrm{H}}$ and $\alpha-\mathrm{MPP}_{\mathrm{L}}$, throughout the Dictyostelium life cycle. The larger form, $\alpha-\mathrm{MPP}_{\mathrm{H}}$, is cleaved to produce the functional $\alpha-\mathrm{MPP}_{\mathrm{L}}$ form. We were not able to isolate mutants in which the $\alpha$-mpp gene had been disrupted. Instead, an antisense transformant, $\alpha$ A2, expressing $\alpha$-MPP at a lower level than the wild-type AX-3 was isolated to examine the function of the $\alpha$-MPP protein. Development of the $\alpha \mathrm{A} 2$ strain was normal until the slug formation stage, but the slug stage was prolonged to $\sim 24 \mathrm{~h}$. In this prolonged slug stage, only $\alpha-\mathrm{MPP}_{\mathrm{H}}$ was present, and $\alpha-\mathrm{MPP} \mathrm{P}_{\mathrm{L}}$ protein and MPP activity were not detected. After $28 \mathrm{~h}, \alpha-\mathrm{MPP}_{\mathrm{L}}$ and MPP activity reappeared, and normal fruiting bodies were formed after a delay of approximately $8 \mathrm{~h}$ compared with normal development. These results indicate that MPP activity is controlled by the processing of $\alpha-\mathrm{MPP}_{\mathrm{H}}$ to $\alpha-\mathrm{MPP}_{\mathrm{L}}$ during development in Dictyostelium.
\end{abstract}

\section{INTRODUCTION}

In eukaryotes, mitochondria are important as the energygenerating organelles and also play important roles in cellular functions, including the synthesis of metabolites, the metabolism of lipids, nucleotides and iron, and signalling pathways (Lill \& Kispal, 2000; Newmeyer \& FergusonMiller, 2003). Cells possess a mitochondrial genome as well as a nuclear genome. Yeast and human mitochondrial genomes encode only eight and 13 proteins, respectively, which are the subunits of the respiratory chain and oxidative phosphorylation (Foury et al., 1998; Scarpulla, 2006). The other proteins in mitochondria are encoded by the nuclear genome and have to be imported into the organelles from the cytosol.

The majority of mitochondrial proteins encoded by nuclear genes are synthesized on cytoplasmic ribosomes as larger

†Present address: Faculty of Life Sciences, University of Manchester, Manchester M13 9PT, UK.

Abbreviations: AP, alkaline phosphatase; COX IV, cytochrome c oxidase subunit IV; GST, glutathione S-transferase; MIP, mitochondrial intermediate peptidase; MPP, mitochondrial processing peptidase; MTS, mitochondrial targeting signal.

The GenBank/EMBL/DDBJ accession number for the $\alpha$-MPP cDNA sequence of Dictyostelium discoideum is AB213513. precursors with a presequence called the mitochondrial targeting signal (MTS) sequence at the $\mathrm{N}$ terminus, which is a signal for targeting the protein to mitochondria. During or after import of the precursor proteins into the mitochondria, the presequences are removed by the mitochondrial processing peptidase (MPP; EC 3.4.24.64) to form the mature proteins (Ito, 1999; Gakh et al., 2002; Koehler, 2004). Some precursor proteins are first cleaved by MPP, and then the remaining octapeptide of the presequence is removed by an additional mitochondrial intermediate peptidase (MIP; EC 3.4.24.59), resulting in the mature proteins (Hendrick et al., 1989; Gavel \& von Heijne, 1990; Branda \& Isaya, 1995; Ito, 1999). MPP is a heterodimeric metalloendopeptidase consisting of two non-identical subunits called $\alpha$ - and $\beta$-MPP. $\alpha$-MPP participates in the recognition of the N-terminal presequences (Luciano et al., 1997; Shimokata et al., 1998), and $\beta$-MPP functions as a catalytic subunit and contains a metal $\left(\mathrm{Zn}^{2+}\right)$-binding motif at the active site (Kitada et al., 1995, 1998; Luciano et al., 1998). The $\alpha$ - and $\beta$-MPP subunits act cooperatively to remove the $\mathrm{N}$-terminal presequences of the precursor proteins (Kojima et al., 1998).

The cellular slime mould Dictyostelium discoideum grows vegetatively as unicellular amoebae. Once nutrients are 
depleted, the amoebae aggregate and eventually form a fruiting body containing spores supported on a stalk. Because of its unique life cycle, $D$. discoideum has been used as a model organism to study developmental processes. During the life cycle, mitochondria of $D$. discoideum exhibit marked morphological changes that appear to be closely related to the regulation of development (Ashworth et al., 1969; Cotter et al., 1969; Maeda, 1971; George et al., 1972). Mitochondrial dysfunction is caused by mutations in nuclear genes encoding mitochondrial proteins. In Dictyostelium, deficiencies in certain nuclear-encoded mitochondrial proteins cause defects in chemotaxis to cAMP (van Es et al., 2001), in cell-type differentiation (Kotsifas et al., 2002), and in spore maturation (Morita et al., 2005). Also, antisense RNA inhibition of nuclear gene-encoded mitochondrial proteins results in a phototaxis deficiency (Kotsifas et al., 2002; Bokko et al., 2007), and depletion of mitochondrial DNA (mtDNA) causes deficiencies in cell aggregation (Inazu et al., 1999) and in cell-type differentiation (Wilczynska et al., 1997; Chida et al., 2004). Disruption of the rps4 gene in mtDNA causes a failure of Dictyostelium cells to initiate differentiation (Chida et al., 2008). Recently, Nagayama et al. (2008) showed that mitochondrial dysfunction caused by $\beta$-mpp antisense inhibition is compensated in a retrograde signalling manner. Despite increasing focus on novel mitochondrial functions in development, little is known about basic mitochondrial biogenesis in $D$. discoideum.

In this paper, we report the cloning of a cDNA encoding the $\alpha$ subunit of Dictyostelium MPP (Dd $\alpha$-MPP), the structural features of $\mathrm{Dd} \alpha-\mathrm{MPP}$, and the expression of the $\alpha$-MPP gene $(m p p A)$ during Dictyostelium development. We also show that the processing of $\alpha$-MPP is necessary for MPP activity expression and for development in Dictyostelium.

\section{METHODS}

Strain, culture and development of Dictyostelium. D. discoideum strain AX-3 was grown axenically in HL-5 medium (Sussman \& Sussman, 1967) supplemented with $100 \mu \mathrm{g}$ streptomycin $\mathrm{ml}^{-1}$ at $22{ }^{\circ} \mathrm{C}$ on a reciprocal shaker ( 150 r.p.m.). Vegetative amoebae at a

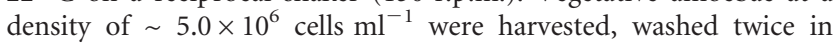
$12 \mathrm{mM}$ sodium phosphate buffer ( $\mathrm{pH} \mathrm{6.7)}$, and resuspended in development buffer PDF ( $13 \mathrm{mM} \mathrm{KCl}, 10 \mathrm{mM} \mathrm{NaH} \mathrm{PO}_{4}, 25 \mathrm{mM}$ $\mathrm{NaH}_{2} \mathrm{PO}_{4}, 0.8 \mathrm{mM} \mathrm{CaCl}_{2}, 5 \mathrm{mM} \mathrm{MgSO}_{4}$ ) at $1.5 \times 10^{8}$ cells $\mathrm{ml}^{-1}$. Approximately $1.0 \times 10^{7}$ cells were plated onto nitrocellulose filters (Millipore, type HABP, $0.45 \mu \mathrm{m}$ pore-size, diameter $47 \mathrm{~mm}$ ) for multicellular development.

Isolation of nuclei, nucleic acids and mitochondria. The isolation of nuclei, genomic DNA and total RNA from Dictyostelium amoebae was performed using general methods as previously described (Nagayama et al., 2008). Mitochondria were isolated from vegetatively growing cells, as previously described (Nagayama et al., 2008).

Screening of $\alpha$-MPP cDNA clone, sequencing and analysis. A 3' region (604 bp long) of $\alpha$-subunit cDNA (contig U14151-1) of Dictyostelium MPP has been reported by the Dictyostelium cDNA project (http://dictycdb.biol.tsukuba.ac.jp/). To amplify a part of the $\alpha$-MPP gene, two oligonucleotide primers, mpp- $\alpha 1$ (5'-GAGGATCCTTGTTGGGTGGTGGCAGTTC-3', containing 20 nucleotides from positions 1441 to 1460 of $\alpha$-mpp cDNA) and mpp- $\alpha 2$ (5'-GAGAATTCATGTCTAGCGATATCATCAC-3', containing 20 nucleotides complementary to the sequence from positions 1751 to 1771), were designed. These primers contained BamHI and EcoRI sites (underlined) at the $5^{\prime}$ ends. PCR amplification was performed on Dictyostelium genomic DNA using these primers, as described previously (Nagayama et al., 2008). The amplified fragment of 330 bp was sequenced for confirmation. By screening a $\lambda Z A P$ II cDNA library (kindly provided by Dr Herbert L. Ennis, Columbia University) using the digoxigenin-dUTP-labelled PCR fragment as a probe, a positive clone ( $\mathrm{pB} \propto \mathrm{mpp}$ ) was isolated, which is a plasmid containing the fulllength $\alpha$-mpp cDNA inserted between the EcoRI and XhoI sites of Bluescript. The nucleotide sequencing and analysis of $\mathrm{pB} \alpha \mathrm{mpp}$ were performed as described previously (Nagayama et al., 2008).

Construction of plasmids pDampp237-gfp, pDampp237-gst and pET $\alpha$ mpp237-gst. The EcoRI fragment (encoding the first 237 amino acids) from $\mathrm{pB} \alpha \mathrm{mpp}$ was subcloned into the EcoRI site of pBluescript SKII $(-)$ to yield plasmid pBampp237. The GFP gene was PCR-amplified using pUC118H-gfp as a template with the forward primer (5'-GGAAACAGCTATGACCATGATTTACG-3') and the reverse primer $\left(5^{\prime}\right.$-GCTCTCGAGTTACTTGTACAGCTCGTC- $\left.3^{\prime}\right)$. The underlining in the reverse primer indicates the XhoI site introduced for subcloning. The PCR product was digested with HindIII and XhoI, and then fused in-frame at the $5^{\prime}$ end with the $3^{\prime}$ end of the $\alpha \mathrm{mpp} 237$ in $\mathrm{pB} \alpha \mathrm{mpp} 237$, to generate the construct pBampp237-gfp. The BamHI/Xhol fragment (containing an ampp237-gfp fusion gene) from $\mathrm{pB} \alpha \mathrm{mpp} 237$-gfp was subcloned between the BamHI and XhoI sites of the Dictyostelium expression vector pDNeo67, to yield the construct pDampp237-gfp. The PCRamplified GFP gene was also subcloned into pDNeo67 to obtain pDgfp. To construct plasmid pDampp237-gst, the glutathione $S$ transferase (GST) gene was amplified using pGEX-2T (Pharmacia Biotech) as a template with a set of primers (forward primer, $5^{\prime}$ CAGAAGCTTATGTCCCCTATACTAGG-3'; reverse primer, 5' TCTCTCGAGTTAACGCGGAACCAGATCC-3'). The underlined bases in the two primers indicate HindIII and XhoI sites, respectively. Using the amplified PCR product, a plasmid, pD $\alpha \mathrm{mpp} 237$-gst, was constructed in a manner similar to the construction procedure of pD $\alpha$ mpp237-gfp described above. For the expression of $\alpha$ MPP237GST in Escherichia coli, the $\alpha \mathrm{mpp} 237$-gst fragment from pD $\alpha \mathrm{mpp} 237-$ gst was subcloned into a pET15b vector (Novagen) to make plasmid pET $\propto$ mpp237-gst.

Preparation of $\alpha$-MPP overexpressing and $\alpha-m p p$ antisense transformants. The BamHI/XhoI fragment from $\mathrm{pB} \alpha \mathrm{mpp}$ was inserted between the same sites of $\mathrm{pDNeo67}$ to generate $\mathrm{pD} \alpha \mathrm{mpp}$. The constructed plasmid was introduced into AX-3 cells by electroporation by the method of Howard et al. (1988), and transformed cells were selected in HL-5 medium containing $10 \mu \mathrm{g}$ G418 $\mathrm{ml}^{-1}$ to obtain the $\alpha$-MPP-overexpressing transformants (the $\alpha^{\mathrm{OE}}$ strain). The $\alpha$-mpp antisense transformants of Dictyostelium were isolated as described in our previous paper (Nagayama et al., 2008). Also, as a control, the $\alpha-m p p$ sense transformant was isolated (Nagayama et al., 2008).

Analysis of gene expression by real-time quantitative PCR. Real-time quantitative PCR was performed for quantification of the $\alpha$-MPP mRNA during development of the wild-type strain, as previously described (Nagayama et al., 2008). The sense primer ( $5^{\prime}$ GTCCAGGTAAGGGTATGCAAAGTAG-3', corresponding to positions 1475-1499 in the cDNA sequence) and the antisense primer (5'-ATTGTTCAGCAGTTAAGATTGGTTC-3', positions 1912-1923) were used. Amplification of the $r n l$ gene was also performed under the 
same conditions for use as an intrinsic normalization control. The amounts of cDNA synthesized from $0.1 \mu \mathrm{g}$ total RNA were measured according to the manufacturer's protocols (Roche Diagnostics).

Preparation of antibodies. The preparation of the anti- $\alpha$-MPP antibody against the N-terminally truncated $\alpha$-MPP $(\alpha-\mathrm{MPP} \Delta \mathrm{N}$, $47 \mathrm{kDa}$ ) and anti-COX IV antibody has been described in our previous paper (Nagayama et al., 2008). The antisera containing anti- $\alpha$-MPP and anti-COX IV antibodies were tested by Western blot analysis.

\section{Assay of enzyme activities}

MPP activity. The substrate (precursor protein) for MPP activity assay was prepared as follows. DdCOX IV cDNA was PCR-amplified from the VSK134 cDNA clone for COX IV (Dictyostelium cDNA project) using the forward primer cox4f(nco) (5'-GAGAGCCATGGTTGCTTTAAGATCAATTCG-3') and the reverse primer cox4r(bam) $\left(5^{\prime}\right.$ TAAGGATCCTTAGTTATTTAAAACTTTGAC-3'). The underlined bases indicate the $\mathrm{NcoI}$ site in the forward primer and the BamHI site in the reverse primer. The PCR product was digested with $N c o$ I and $B a m H I$, and then inserted between the NcoI and BamHI sites of the expression vector $\mathrm{pET} 15 \mathrm{~b}$ to yield the construct pETcox4. A His-tag was added to the $3^{\prime}$ end of COX IV gene, using the oligonucleotide chis(xho) (5'-GCCGCTCGAGCTAATGGTGGTGATGGTGGTGTGA-

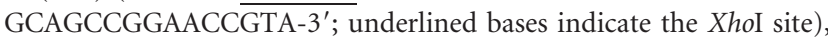
which contains a His-tag sequence and bases complementary to the cloning site of pET15b. The primers $\operatorname{cox} 4 \mathrm{f}(\mathrm{nco})$ and c-his(xho) were used to amplify a cDNA with a His-tag sequence at the $3^{\prime}$ end from pETcox4. The PCR product was digested with NcoI and XhoI and inserted into the corresponding sites of pET15b to generate the construct pETcox4-his. E. coli AD494(DE3) was transformed with pETcox4-his, and the resultant transformant was cultured in the presence of $0.5 \mathrm{mM}$ isopropyl- $\beta$-thio-D-galactopyranoside. The COX IV-His protein, strongly expressed in an inclusion body, was purified and used as a substrate (precursor protein) for the MPP enzyme activity assay. The precursor protein (COX IV-His) was incubated with the crude extract or the mitochondrial fraction $(20 \mu \mathrm{g}$ protein) in reaction buffer containing $30 \mathrm{mM}$ Tris/ $\mathrm{HCl}(\mathrm{pH} 8.0)$ at $4{ }^{\circ} \mathrm{C}$ for $15 \mathrm{~min}$. The reaction was stopped by adding SDS buffer (25 mM Tris/ $\mathrm{HCl}, \mathrm{pH} 6.5,10 \mathrm{mM} \beta$-mercaptoethanol, $1 \%$ SDS, $10 \%$ glycerol, $0.01 \%$ bromophenol blue). The processing protein products were separated by SDS-PAGE and visualized by immunostaining with antiCOX IV antiserum or anti-His-tag antibody (Invitrogen), as described for Western blot analysis.

$\alpha-\mathrm{MPP}_{\mathbf{H}}$ processing activity. The extract containing $\alpha-\mathrm{MPP}_{\mathrm{H}}$ but no $\alpha-\mathrm{MPP}_{\mathrm{L}}$ was prepared from the $\alpha^{\mathrm{OE}}$ strain cells developed at $16 \mathrm{~h}$ or the slug cells developed for $24 \mathrm{~h}$ on non-nutrient $\mathrm{H}_{2} \mathrm{O}$-agar plates according to the method of Fisher \& Annesley (2006), and was used as a substrate to determine $\alpha-\mathrm{MPP}_{\mathrm{H}}$ processing activity. The extract (20 $\mu \mathrm{g}$ protein) containing $\alpha-\mathrm{MPP}_{\mathrm{H}}$ was incubated at $4{ }^{\circ} \mathrm{C}$ for $16 \mathrm{~h}$ with the crude extract $(20 \mu \mathrm{g}$ protein) prepared from vegetative or developing cells. The conversion protein products were separated by SDS-PAGE and visualized with anti- $\alpha \mathrm{MPP}$ antiserum and goat anti-mouse IgG-alkaline phosphatase (AP), as described for Western blot analysis.

Western blot analysis. Total proteins were extracted from the cells at various developmental stages by sonication or by grinding with glass beads. Protein concentration was measured by the Lowry method (Lowry et al., 1951), using BSA as a standard. Samples of protein $(20 \mu \mathrm{g}$; or $150 \mu \mathrm{g}$ in the case of expression analysis of $\alpha$-MPP) were separated by SDS-PAGE and then electroblotted onto PVDF membranes (Bio-Rad). Blots were blocked with $5 \%$ skimmed milk and then incubated with anti- $\alpha$-MPP antiserum or anti-COX IV antiserum (1:500 dilution) for $90 \mathrm{~min}$. The blots were then incubated with goat anti-mouse IgG-linked AP (1:1500 dilution; Dako Cytomation) for $60 \mathrm{~min}$. Protein bands were visualized using 4-nitroblue tetrazolium chloride (NBT) and 5-bromo-4-chloro-3indolyl phosphate (X-phosphate) as substrates. Precision Plus protein standards (Bio-Rad) and Prestained Protein Marker (New England Biolabs) were used as protein size markers.

Fluorescence microscopy. Transformed cells expressing the aMPP237-GFP fusion protein were grown in HL-5 medium with shaking. The mitochondria were labelled with MitoTracker Red 580 (Invitrogen Molecular Probes) at a concentration of $100 \mathrm{nM}$ in HL-5 medium. The cells were washed four times in fresh HL-5 medium to remove unbound MitoTracker Red. The cells were resuspended at $1 \times 10^{6}$ cells ml $^{-1}$ and mounted for fluorescence microscopy (Olympus BX50). The images were analysed using IPLab Scientific Imaging Software (Scanalytics).

\section{RESULTS}

\section{Isolation of the $\alpha$-MPP cDNA clone and characterization of Dd $\alpha$-MPP}

A full-length cDNA clone of $\operatorname{Dd} \alpha-\mathrm{MPP}$ (pB $\alpha \mathrm{mpp}$ ) was isolated from a Dictyostelium $\lambda$ ZAP II cDNA library. The cDNA encoded a protein of 654 amino acids with a calculated molecular mass of 73258 . The gene ( $m p p A)$ encoding $\alpha$-MPP is located on chromosome 2 , and its nucleotide sequence is available in contig DDB0232199 from the Dictyostelium genome project (http://dictybase.org).

The amino acid sequence of $\mathrm{Dd} \alpha$-MPP was compared with those of the known $\alpha$-MPPs from other organisms. Dd $\alpha$ MPP had amino acid identities of $25-27 \%$ and similarities of $43-47 \%$ with known $\alpha$-MPPs. The domain structure of Dd $\alpha$-MPP is shown in Fig. 1(a). A highly conserved glycine-rich domain (GGGSSYSTGGPKGM), which is predicted to form a loop that might be involved in substrate binding and/or product release (Nagao et al., 2000), is conserved in Dd $\alpha$-MPP. The glutamate/aspartate residues that are well-conserved in other $\alpha$-MPPs, and which might recognize the distal basic amino acid of the MTS peptide (Shimokata et al., 1998), are also conserved in Dd $\alpha$-MPP as the sequence $\mathrm{D}^{579} \mathrm{D}^{580}$. Dd $\alpha$-MPP contains an asparaginerich region $[\operatorname{poly}(\mathrm{N})$ cluster] from positions 51 to 100 in the N-terminal region. An extra sequence containing a glutamine stretch [poly $(\mathrm{Q})$ cluster] and a high level of acidic amino acids is located from positions 388 to 450 . These repeated sequences are common in Dictyostelium proteins, and their functions remain unknown (Eichinger et al., 2005).

\section{Subcellular localization of $\alpha$-MPP}

Dd $\alpha$-MPP does not contain a typical MTS sequence at the $\mathrm{N}$ terminus, which is rich in basic, hydrophobic and hydroxylated amino acids, and forms an amphiphilic $\alpha$ helix (von Heijne et al., 1989; von Heijne, 1990). However, fractionation of mitochondria showed that $\operatorname{Dd} \alpha-\mathrm{MPP}$ localizes in the mitochondrial matrix fraction (Nagayama et al., 2008). In order to confirm that $\alpha$-MPP has a targeting signal and can be imported into mitochondria, an aMPP237-GFP fusion protein, in which the N-terminal 
(a)

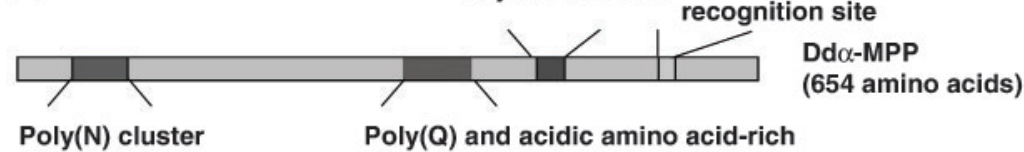

Poly(N) cluster

(b)

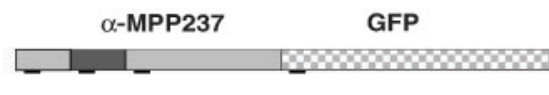

GFP

$\alpha$ MPP237-GFP
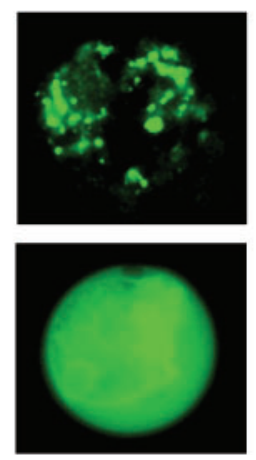

MitoTracker
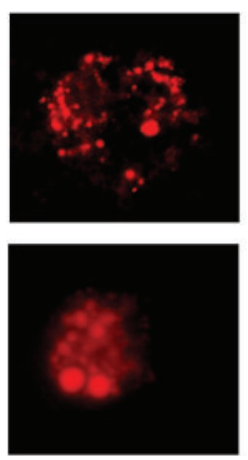

QMPP237-GFP

Merged
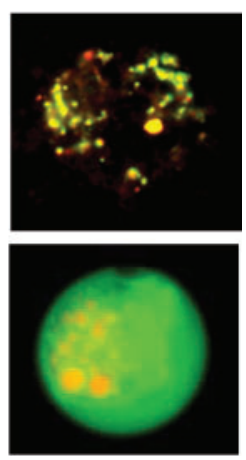

Fig. 1. Domain structure of Dd $\alpha$-MPP and intracellular localization of aMPP237-GFP. (a) Schematic representation of the domain structure of Dd $\alpha$-MPP. The map shows the positions of the functional domains of $\mathrm{Dd} \alpha$ MPP. The well-conserved Gly-rich domain (GGGSSYSTGGPKGM) and distal basic amino acid recognition site (DD) are located in the C-terminal half of the Dd $\alpha$-MPP molecule. There is a poly $(\mathrm{N})$ cluster in the $\mathrm{N}$ terminal region and a poly $(\mathrm{Q})$ and acidic amino acid-rich region in the middle region. (b) Localization of $\alpha$ MPP237-GFP, a fusion protein in which the $\mathrm{N}$-terminal 237 amino acids of $\alpha$-MPP are fused to GFP. The fluorescence image of Dictyostelium cells transformed with constructs $\mathrm{pD} \alpha \mathrm{mpp} 237$-gfp (upper row) and pDgfp (lower row) are shown. The first column shows the GFP fluorescence image, and the second column the MitoTracker Red fluorescence image. The last column shows the merged image for the localization of $\alpha$ MPP237-GFP fusion protein. The localization of GFP alone, as a control, is also shown by the fluorescence image. A schematic map of $\alpha$ MPP237-GFP is shown above the panels. region (the first 237 amino acids) of $\alpha$-MPP is fused at the C-terminal end to GFP, was generated (Fig. 1b). aMPP237-GFP was located in the mitochondria labelled with MitoTracker Red (Fig. 1b). GFP alone, as a negative control, was localized in the cytosol (Fig. 1b). These results suggest that the $\mathrm{N}$-terminal region of $\alpha$-MPP harbours a targeting signal to directly import $\alpha$-MPP into the mitochondria. The MTS sequence of $\alpha$-MPP remains to be identified.

\section{Mitochondrial processing activity in Dictyostelium cells}

Cytochrome $c$ oxidase subunit IV (COX IV), a protein localized in the inner membrane of mitochondria, is synthesized in the cytosol as a precursor protein with an MTS sequence at the $\mathrm{N}$ terminus, imported into the mitochondria, and subsequently processed by MPP and MIP to yield the mature form (Maarse et al., 1984; Branda \& Isaya, 1995; Gakh et al., 2002). Fig. 2(a) shows the Nterminal amino acid sequence of DdCOX IV and its putative MPP and MIP cleavage sites. We measured the processing activities of mitochondria using a recombinant DdCOX IV precursor $(17 \mathrm{kDa})$ as a substrate. As shown in Fig. 2(b), MPP cleaved the precursor to generate the intermediate form $(14.3 \mathrm{kDa})$. When incubated at temperatures over $20{ }^{\circ} \mathrm{C}$, the intermediate form was further cleaved by MIP to yield the mature form (13.4 kDa). MPP activity was also detected at the relatively low temperatures of 0 and $4{ }^{\circ} \mathrm{C}$. So, MPP activity was measured at $4{ }^{\circ} \mathrm{C}$ to eliminate MIP activity in the crude extracts. MPP activity was present in the mitochondrial soluble (matrix) fraction but not in the mitochondrial insoluble (membrane) fraction (Fig. 2c).

\section{Expression of $m p p A$ is developmentally regulated}

To examine the levels of $\alpha$-MPP mRNA during Dictyostelium development, Northern blotting was performed. However, no band was detected, suggesting that the expression level of $\alpha$-MPP mRNA is quite low. To measure the amounts of $\alpha$-MPP mRNA, real-time quantitative PCR was performed on cDNA from developing cells at the indicated times. Expression of mitochondrial large subunit rRNA $(r n l)$, which is constitutively expressed by a mitochondrial gene, was used as an internal control (Early et al., 1988). Fig. 3 shows the normalized relative amounts of $\alpha$-MPP cDNA synthesized from $0.1 \mu \mathrm{g}$ total RNA at the indicated times. The expression of $\alpha$-MPP mRNA was highest in vegetative cells $(0 \mathrm{~h})$ and at the early development stage $(10 \mathrm{~h})$, and then markedly decreased at $14 \mathrm{~h}$ of development, indicating that transcription of the $\alpha$-MPP gene is strongly downregulated at this time.

\section{Processing of an immature form of Dd $\alpha$-MPP is necessary for MPP enzyme activity}

To examine whether the level of $\alpha$-MPP protein is similarly regulated throughout development, Western blot analysis was performed using anti- $\alpha$-MPP antiserum against the 
(a)

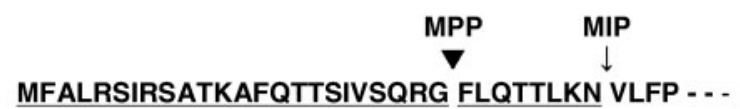

(b)

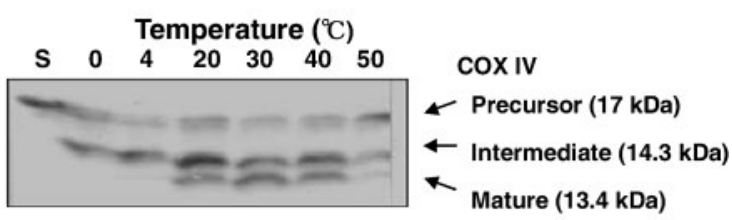

(c)

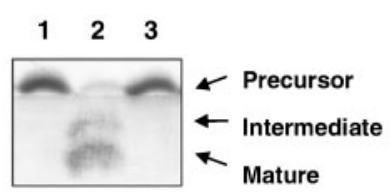

Fig. 2. Processing peptidase activities of MPP and MIP. (a) $\mathrm{N}$-terminal amino acid sequence of the DdCOX IV precursor. The MPP and MIP cleavage sites are indicated by an arrowhead and an arrow, respectively. (b) Mitochondrial processing activities. The precursor of DdCOX IV (tagged with a His-tag at the $\mathrm{C}$ terminus) was incubated at temperatures between 0 and $50{ }^{\circ} \mathrm{C}$ for $15 \mathrm{~min}$ with the mitochondrial fraction $(20 \mu \mathrm{g}$ protein) isolated from vegetative cells in reaction buffer, as described in Methods. Processing peptides were subjected to SDS-PAGE, followed by Western blot analysis and immunostaining using the anti-His-tag antibody. Lane $\mathrm{S}$ contains substrate alone. Numbers indicate temperature $\left({ }^{\circ} \mathrm{C}\right)$ of the reaction. (c) MPP activity in the mitochondrial subfractions. The mitochondria isolated were disrupted by sonication and then centrifuged at $14000 \mathrm{~g}$ for $1 \mathrm{~h}$, yielding the soluble and insoluble fractions. MPP activity of these fractions was measured using DdCOX IV precursor as a substrate, as described above. Lane 1, substrate alone; lanes 2 and 3 , soluble and insoluble fractions, respectively.

$\mathrm{N}$-terminally truncated $\alpha$-MPP. In vegetative cells $(0 \mathrm{~h})$, two major bands of 65 and $60 \mathrm{kDa}$ were detected by the antiserum. The $60 \mathrm{kDa}$ protein was expressed at slightly higher levels than the $65 \mathrm{kDa}$ protein (Fig. 4a). The $65 \mathrm{kDa}$ protein was designated $\alpha-\mathrm{MPP}_{\mathrm{H}}$, and the smaller $60 \mathrm{kDa}$ protein as $\alpha-\mathrm{MPP}_{\mathrm{L}} \cdot \alpha-\mathrm{MPP}_{\mathrm{H}}$ was expressed at the same level in developing cells from 0 to $16 \mathrm{~h}$, and then the amount of this protein in developing cells decreased rapidly after $20 \mathrm{~h}$. By comparison, there was little change in the amount of $\alpha-\mathrm{MPP}_{\mathrm{L}}$ in developing cells from 0 to $8 \mathrm{~h}$, a decrease at $12 \mathrm{~h}$, and then a marked increase thereafter.

To examine the expression of MPP activity during development, the enzyme activity at various developmental stages was measured using the COX IV precursor as a substrate. MPP activity was largely constant at all stages of development, although cells at $12 \mathrm{~h}$ of development exhibited slightly lower activity (Fig. 4b), suggesting a correlation between the expression pattern of MPP activity and that of $\alpha-\mathrm{MPP}_{\mathrm{L}}$. These results for the expression of $\alpha$ -

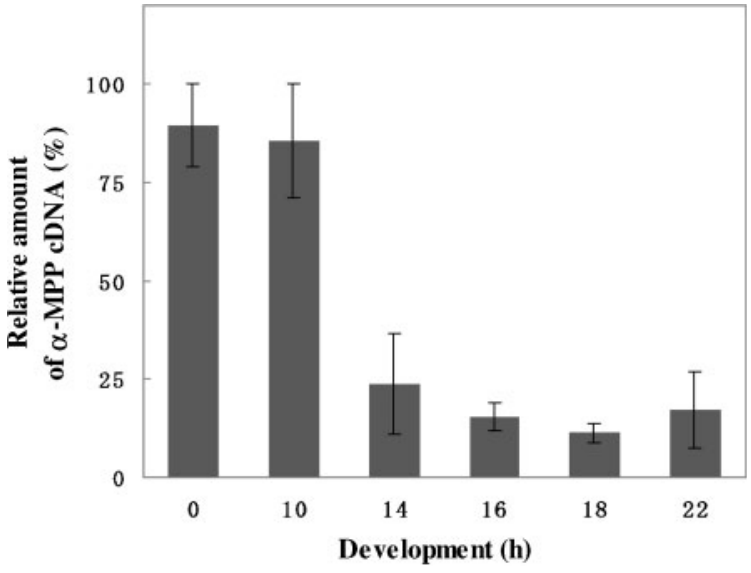

Fig. 3. Expression of $\alpha$-MPP mRNA during development. Normalized relative amounts of $\alpha$-MPP cDNA from total RNA at the indicated developmental times. Real-time PCR was performed as described in Methods. The mean values of the results obtained from two independent experiments are shown.

MPP and MPP activity during development were confirmed reproducibly in several experiments. On the other hand, $\beta$-MPP is expressed at a size of $52 \mathrm{kDa}$ at almost the same level throughout development, as described previously (Nagayama et al., 2008).

In order to investigate the relationship between $\alpha-\mathrm{MPP}_{\mathrm{L}}$ and MPP activity, we focused on slug-stage cells because the beginning of the slug stage is at about $12 \mathrm{~h}$ of development. To completely separate the slug cells from cells at other stages of development, the wild-type cells were allowed to develop on non-nutrient $\mathrm{H}_{2} \mathrm{O}$-agar plates, according to the method of Fisher \& Annesley (2006). Aggregation mounds were formed at about $12 \mathrm{~h}$ of development, and the slug was subsequently formed. When developed for an additional $12 \mathrm{~h}$, the slug did not proceed to the following developmental stage and the slug-stage state was maintained, as described by Newell et al. (1969). As shown in Fig. 4(c, d), in the slug cells that had developed for $24 \mathrm{~h}$ [slug $(24 \mathrm{~h})$ ], only $\alpha-\mathrm{MPP}_{\mathrm{H}}$ was present and MPP activity was not detected, suggesting that $\alpha$ $\mathrm{MPP}_{\mathrm{L}}$, not $\alpha-\mathrm{MPP}_{\mathrm{H}}$, is the mature active form of $\alpha-\mathrm{MPP}$ that associates with the $\beta$-MPP subunit to form the functional MPP with its enzyme activity.

\section{$\alpha-\mathrm{MPP}_{\mathrm{H}}$ is processed to $\alpha-\mathrm{MPP}_{\mathrm{L}}$ by removing its $\mathbf{N}$-terminal region}

To examine whether the $\mathrm{N}$-terminal region of $\alpha-\mathrm{MPP}_{\mathrm{H}}$ is removed or not, $\alpha \mathrm{MPP} 237-\mathrm{GST}$ was expressed in Dictyostelium cells, because $\alpha$ MPP237-GFP is located in the mitochondria as described above. When $\alpha$ MPP237-GST was expressed in Dictyostelium cells, two protein bands of 42 and $38 \mathrm{kDa}$ were detected by anti-GST antibody (Fig. 5a), whereas, when expressed in E. coli, a $51 \mathrm{kDa}$ 
(a) $\alpha$-MPP

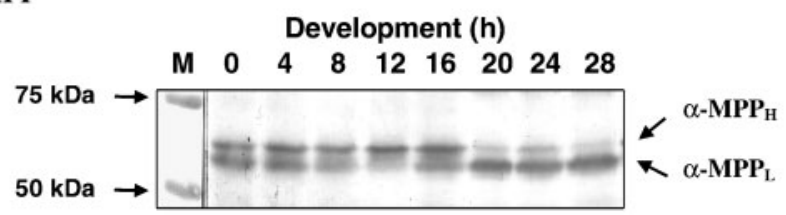

(b) MPP activity

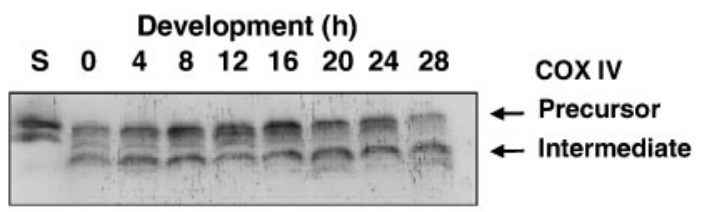

(c) $\alpha$-MPP

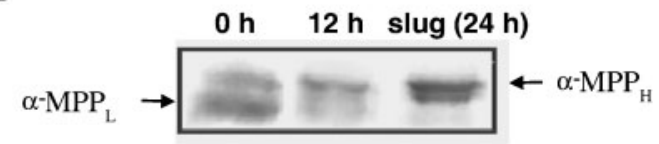

(d) MPP activity

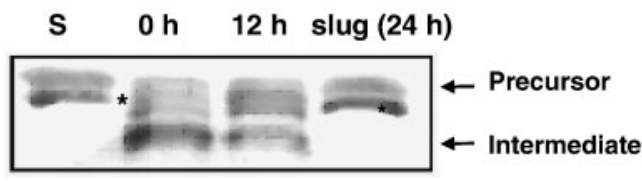

Fig. 4. Expression of $\alpha$-MPP and MPP activity during development in the wild-type strain. (a) Crude extracts $(150 \mu \mathrm{g}$ protein) from developing cells of the wild-type strain at the indicated times were separated on a $9.0 \%$ SDS-PAGE gel and electroblotted onto PVDF membranes. Blots were visualized by immunostaining using anti- $\alpha$-MPP antiserum and antimouse $\lg G-A P$. Lane $M$ indicates marker proteins (75 and $50 \mathrm{kDa}$ ). (b) For MPP activity assay, each fraction (20 $\mu \mathrm{g}$ protein) of crude extract from developing cells at the indicated times was incubated with the DdCOX IV precursor at $4{ }^{\circ} \mathrm{C}$ for $15 \mathrm{~min}$, and then subjected to SDS-PAGE $(12.5 \% \mathrm{gel})$. This was followed by Western blot analysis and immunostaining using anti-COX IV antiserum. Lane S, substrate alone; asterisk, non-specific band. (c, d) Wild-type cells were developed on non-nutrient $\mathrm{H}_{2} \mathrm{O}$-agar plates according to the method of Fisher \& Annesley (2006). Crude extracts were prepared from the vegetative cells $(0 \mathrm{~h})$, cells at $12 \mathrm{~h}$ of development (12 h), and slug cells (24 h). The slug (24 h) was maintained at the slug stage even after an additional $12 \mathrm{~h}$ of development. The expression of $\alpha$-MPP (c) and MPP activity (d) in these cells was examined. protein was detected, which is consistent with the size predicted from the amino acid sequence (Fig. 5b). These two 42 and $38 \mathrm{kDa}$ proteins appear to correspond to $\alpha$ $\mathrm{MPP}_{\mathrm{H}}$ and $\alpha-\mathrm{MPP}_{\mathrm{L}}$, respectively. Taken together, these results indicate that $\alpha \mathrm{MPP} 237-\mathrm{GST}$ is synthesized in the cytosol as a precursor of $51 \mathrm{kDa}$ and imported into the mitochondria to form 42 and $38 \mathrm{kDa}$ proteins, and that $\alpha$ - (a)

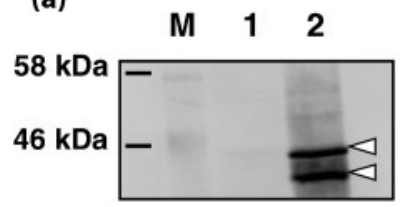

(b)

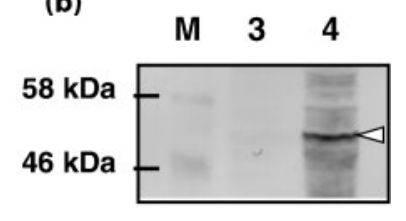

Fig. 5. Expression of $\alpha$ MPP237-GST in D. discoideum and in E. coli. The crude extracts (20 $\mu \mathrm{g}$ protein) from a Dictyostelium transformant ( $\mathrm{pD} \alpha \mathrm{mpp} 237$-gst) (a) and an E. coli transformant (pET $\alpha$ mpp237-gst) (b) were separated on a 9.0\% SDS-PAGE gel and electroblotted onto PVDF membranes. The blots were immunostained using goat anti-GST antibody (GE Healthcare) and rabbit anti-goat IgG-AP (Santa Cruz). Lanes 1 and 3, wildtype $D$. discoideum and $E$. coli, respectively; lanes 2 and 4 , transformants of $D$. discoideum ( $\mathrm{pD} \alpha \mathrm{mpp} 237-\mathrm{gst}$ ) and $E$. coli (pET $\alpha \mathrm{mpp} 237$-gst), respectively; lane $\mathrm{M}$, marker proteins (58 and $46 \mathrm{kDa})$.
$\mathrm{MPP}_{\mathrm{L}}$ is produced from $\alpha-\mathrm{MPP}_{\mathrm{H}}$ by removing the $\mathrm{N}$ terminal region.

\section{$\alpha-$ MPP $_{\mathrm{L}}$ and MPP activity completely disappears around the slug stage in an $\alpha$-MPP- overexpressing strain}

The expression level of $\alpha$-MPP protein appeared very low, and detection of the protein by Western blotting was rather difficult, requiring large amounts of sample to be loaded ( $150 \mu \mathrm{g}$ total protein per lane) and long staining times (overnight). We generated an $\alpha$-MPP-overexpres$\operatorname{sing}\left(\alpha^{\mathrm{OE}}\right)$ strain which expressed full-length $\alpha$-MPP under the control of the actin- 6 promoter and actin- 8 terminator. The strain did not show any notable phenotypic differences in development (data not shown). Western blotting with the crude extract ( $20 \mu \mathrm{g}$ protein) from the $\alpha^{\mathrm{OE}}$ strain easily detected $\alpha$-MPP protein and its expression level in the $\alpha^{\mathrm{OE}}$ strain was much higher (12 times or more) than the wild-type strain (Fig. 6a). $\alpha-\mathrm{MPP}_{\mathrm{H}}$ was highly and almost constantly expressed at about the same level throughout development of the $\alpha^{\mathrm{OE}}$ strain. On the other hand, $\alpha-\mathrm{MPP}_{\mathrm{L}}$ disappeared at 12 and $16 \mathrm{~h}$ of development, and reappeared in culminating and fruiting body-forming stages of development (Fig. 6b, 20-24 h). Corresponding to the absence of $\alpha-\mathrm{MPP}_{\mathrm{L}}$ at 12 and $16 \mathrm{~h}$ of development, MPP activity was also lost during this period (Fig. 6c). This suggests that $\alpha-\mathrm{MPP}_{\mathrm{L}}$ is the active 
(a) Expression of $\alpha$-MPP in the wild-type and $\alpha-\mathrm{MPP}^{\mathrm{OE}}$ strains

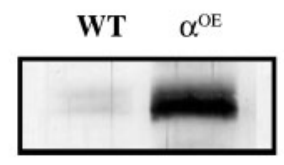

(b) $\alpha$-MPP

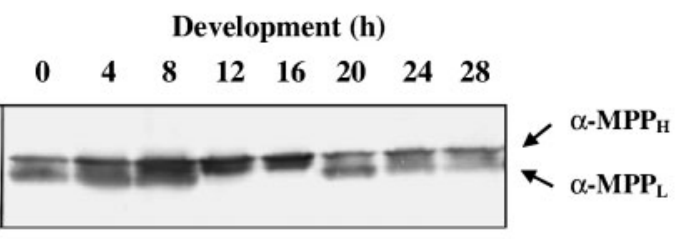

(c) MPP activity

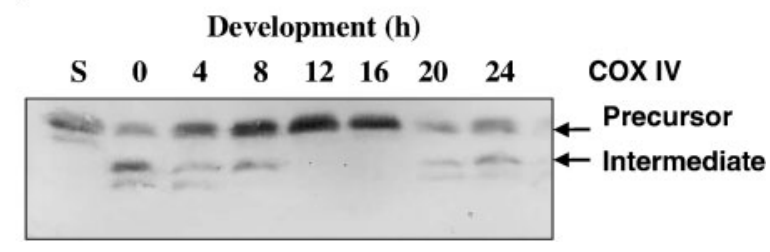

Fig. 6. Expression of $\alpha$-MPP and MPP activity during development in the $\alpha^{\mathrm{OE}}$ strain. (a) The wild-type and the $\alpha^{\mathrm{OE}}$ strains were grown in HL-5 medium in a shaking culture. Crude extracts were prepared from mid-exponentialphase cells of each strain. Crude extracts (20 $\mu \mathrm{g}$ protein) from the wild-type (WT) and the $\alpha^{\mathrm{OE}}$ strains were subjected to SDS-PAGE. $\alpha$-MPP was detected by Western blot analysis using anti- $\alpha$-MPP antiserum by the procedure described in Fig. 4. (b) For analysis of $\alpha$-MPP in the $\alpha^{\mathrm{OE}}$ strain, crude extracts were prepared from developing cells at the indicated times. Each crude extract $(20 \mu \mathrm{g}$ protein) was subjected to SDS-PAGE, followed by Western blot analysis by the procedure described in Fig. 4. (c) The measurements of MPP activity in each crude extract from developing cells at the indicated times were performed using the DdCOX IV precursor as a substrate, as described in Fig. 4. Lane $\mathrm{S}$ indicates substrate alone. form of $\alpha$-MPP. Since $\beta$-MPP is expressed at almost constant levels throughout development (Nagayama et al., 2008), these results indicate that MPP activity is controlled via the maturation of $\alpha$-MPP from the $\alpha-\mathrm{MPP}_{\mathrm{H}}$ form to $\alpha-\mathrm{MPP}_{\mathrm{L}}$.

\section{$\alpha-$ MPP $_{\mathrm{H}}$ processing activity is lost at the slug stage}

When the crude extract $(20 \mu \mathrm{g}$ protein) prepared from wild-type vegetative cells was added to the extract $(20 \mu \mathrm{g}$ protein) from the $\alpha^{\mathrm{OE}}$ cells developed for $16 \mathrm{~h}$, which contained only $\alpha-\mathrm{MPP}_{\mathrm{H}}$ (Fig. 6b, lane 16), $\alpha-\mathrm{MPP}_{\mathrm{H}}$ was converted to $\alpha-\mathrm{MPP}_{\mathrm{L}}$ (Fig. 7, lane 0). As shown in Fig. 6a, since the amount of wild-type $\alpha$-MPP is much less than that of the $\alpha^{\mathrm{OE}}$ strain, the amount of $\alpha$-MPP derived from the wild-type crude extract in the assay mixture is negligible. To examine the expression of processing activity of $\alpha-\mathrm{MPP}_{\mathrm{H}}$ to $\alpha-\mathrm{MPP}_{\mathrm{L}}\left(\alpha-\mathrm{MPP}_{\mathrm{H}}\right.$ processing activity) during development, the enzyme activity at various developmental stages was measured using $\alpha-\mathrm{MPP}_{\mathrm{H}}$ from $\alpha^{\mathrm{OE}}(16 \mathrm{~h})$ cells as a substrate. As shown in Fig. 7 , the processing activity was highest in cells at late development $(20-28 \mathrm{~h})$, moderate in vegetative cells $(0 \mathrm{~h})$, and very weak in cells at early stages ( 4 and $8 \mathrm{~h}$ ). No processing activity was detected in cells at 12 and $16 \mathrm{~h}$ of development. The expression pattern of $\alpha-\mathrm{MPP}_{\mathrm{H}}$ processing activity during development is therefore similar to that of MPP activity and of $\alpha-M_{\mathrm{LPP}}$, even though MPP activity and $\alpha-\mathrm{MPP}_{\mathrm{L}}$ have not completely disappeared in cells at $12 \mathrm{~h}$ development in the wild-type strain (Figs 4 and 7).

\section{Development of an $\alpha-m p p$ antisense strain is delayed}

To investigate the effects of $\alpha$-MPP on development of Dictyostelium, we attempted to isolate knockout mutants of the $m p p A$ gene by homologous recombination. Consistent with similar studies of the $m p p B$ gene (Nagayama et al., 2008), we were unable to isolate a $m p p A$-null strain, suggesting that disruption of the $m p p A$ gene is lethal in Dictyostelium and that MPP plays an essential role in mitochondrial biogenesis and cell proliferation. So, in order

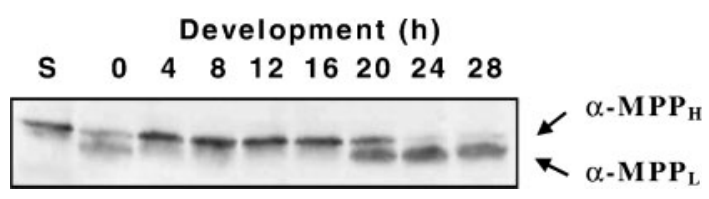

Fig. 7. Expression of $\alpha-M_{\mathrm{PPP}}$ processing activity during development in the wild-type strain. Each crude extract from developing cells at the indicated times was incubated at $4{ }^{\circ} \mathrm{C}$ for $16 \mathrm{~h}$ with $\alpha-\mathrm{MPP}_{\mathrm{H}}$ prepared from the $\alpha^{\mathrm{OE}}$ cells developed at 16 h. $\alpha-\mathrm{MPP}_{\mathrm{H}}$ processing activity for the conversion of $\alpha-\mathrm{MPP}_{\mathrm{H}}$ to $\alpha-\mathrm{MPP}_{\mathrm{L}}$ was analysed by SDS-PAGE, followed by Western blotting using anti$\alpha$-MPP antiserum, as described in Methods. 
to reduce the level of $\alpha$-MPP in cells, we generated an antisense construct to express antisense RNA of the $m p p A$ gene under the control of the actin 6 promoter. A sense construct was also generated as a control (see Methods).

As described in our previous studies (Nagayama et al., 2008), crude extracts prepared from vegetative cells of antisense, sense and the wild-type strains were subjected to SDS-PAGE and then immunostained with anti- $\alpha$-MPP antiserum. $\alpha-\mathrm{MPP}_{\mathrm{H}}$ and $\alpha-\mathrm{MPP}_{\mathrm{L}}$ were detected at the same level in the wild-type and sense strains. Several antisense transformants ( $\alpha \mathrm{A} 1$ to about $\alpha \mathrm{A} 12)$ expressed $\alpha$-MPP $(\alpha-$ $\mathrm{MPP}_{\mathrm{H}}$ and $\left.\alpha-\mathrm{MPP}_{\mathrm{L}}\right)$ at almost the same level as in the wildtype strain or at a slightly lower level. Of these transformants, the $\alpha \mathrm{A} 2$ strain, which expressed $\alpha$-MPP at a slightly lower level than the wild-type strain, was selected for further analysis, as described in previous work (Nagayama et al., 2008). Determination of the $\alpha$-MPP mRNA by semiquantitative RT-PCR revealed a slightly lower level (0.7-fold) of $\alpha$ MPP mRNA in the $\alpha \mathrm{A} 2$ strain relative to the wild-type strain, whereas the mRNAs encoding other mitochondrial proteins, $\beta$-MPP and COX IV, and the actin mRNA (control) were expressed at the same level as in the wildtype strain, as described previously (Nagayama et al., 2008).

Next, we investigated whether the $\alpha \mathrm{A} 2$ strain exhibited any physiologically significant changes in growth and development compared with the wild-type strain. The growth rate of the $\alpha \mathrm{A} 2$ strain was almost the same as that of the wild-type strain (data not shown). Fig. 8 shows the morphological changes of the $\alpha \mathrm{A} 2$ strain during development compared with the wild-type and sense strains. Development of the sense $\alpha \mathrm{S}$ strain was the same as that of the wild-type strain (Fig. 8a, b). In contrast, although development of the $\alpha \mathrm{A} 2$ strain was almost normal until the mound-formation stage (about $12 \mathrm{~h}$ ), the slug stage was lengthened; culmination started late at $24-28 \mathrm{~h}$ of development, and fruiting bodies were only formed at $32 \mathrm{~h}$ (Fig. $8 \mathrm{c})$. Development of the $\alpha \mathrm{A} 2$ strain was therefore delayed by approximately $8 \mathrm{~h}$ compared with the wild-type strain. Other antisense strains with less reduction of $\alpha$-MPP than the $\alpha \mathrm{A} 2$ strain exhibited similar development to the $\alpha \mathrm{A} 2$ strain, except for the $\sim 2-4$ h delay (data not shown).

Fig. 9 shows the expression of $\alpha$-MPP protein, MPP activity and $\alpha-\mathrm{MPP}_{\mathrm{H}}$ processing activity throughout development in the $\alpha \mathrm{A} 2$ strain. Although $\alpha-\mathrm{MPP}_{\mathrm{L}}$ was expressed in cells until $8 \mathrm{~h}$ of development, it was not expressed in cells during late development from 12 to 24 h (Fig. 9a). Only $\alpha$ $\mathrm{MPP}_{\mathrm{H}}$ was present during this late period of development. MPP activity was high in vegetative cells and then decreased markedly by $8-12 \mathrm{~h}$ of development. MPP activity was not detected from 16 to $24 \mathrm{~h}$ of development, but reappeared at $28 \mathrm{~h}$ (Fig. 9b). The expression pattern of $\alpha-\mathrm{MPP}_{\mathrm{H}}$ processing activity was similar to that of MPP activity (Fig. 9c).

\section{(a) Wild-type}

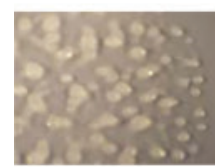

12

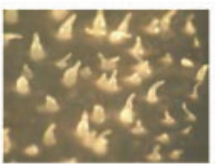

16

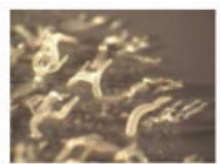

18

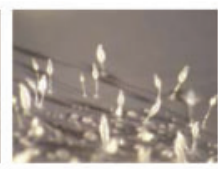

22

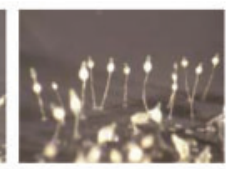

24

(b) $\alpha \mathbf{S}$

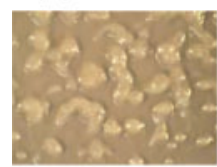

12

(c) $\alpha \mathbf{A 2}$

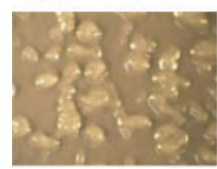

12

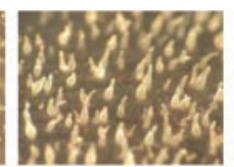

16

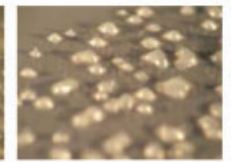

16

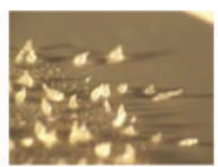

18

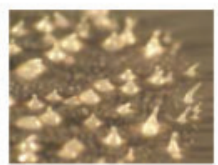

18

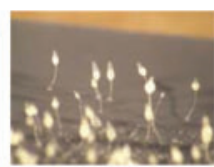

22

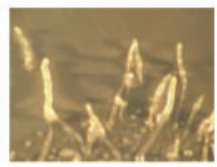

22

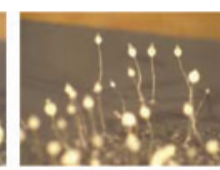

24

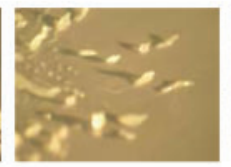

24

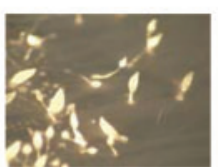

28

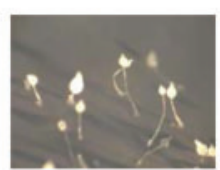

30

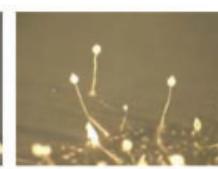

32

Development (h)

Fig. 8. Morphology of developing cells of the $\alpha A 2$ strain. Growing cells of the wild-type (a), sense $\alpha \mathrm{S}$ (b) and antisense $\alpha \mathrm{A} 2$ (c) strains were plated onto nitrocellulose filters, developed under standard conditions, and then photographed at the indicated times. 
(a) $\alpha-M P P$

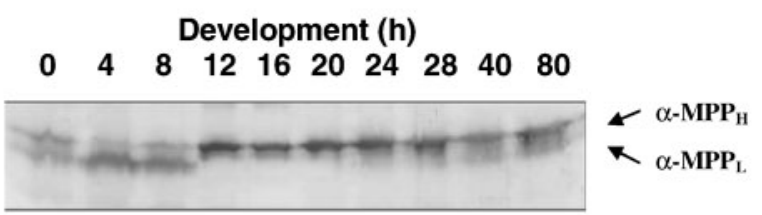

(b) MPP activity

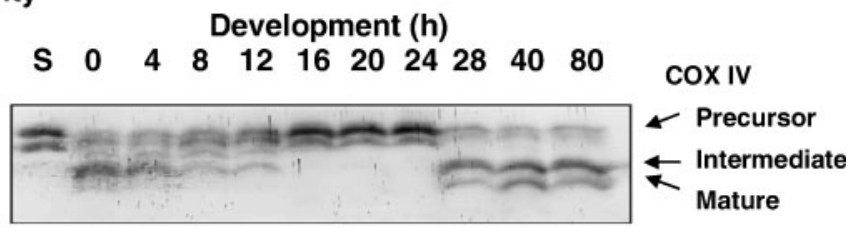

Fig. 9. Analysis of $\alpha$-MPP expression, MPP activity and $\alpha-\mathrm{MPP}_{\mathrm{H}}$ processing activity during development in the $\alpha \mathrm{A} 2$ strain. (a) Crude extracts were prepared from the developing cells of the $\alpha \mathrm{A} 2$ strain at the indicated times. Western blotting and immunostaining were performed by the procedure described in Fig. 4. (b) The measurements of MPP activity in crude extracts were performed using the DdCOX IV precursor, as described in Fig. 4. (c) The measurements of $\alpha-\mathrm{MPP}_{\mathrm{H}}$ processing activity in crude extracts were performed using $\alpha-\mathrm{MPP}_{\mathrm{H}}$ as a substrate, as described in Methods.

Taken together, these results show that $\alpha$-mpp antisense RNA causes a prolonged slug stage at which $\alpha-M_{P} P_{L}$ protein, MPP activity and $\alpha-\mathrm{MPP}_{\mathrm{H}}$ processing activity are absent. When these activities reappear, the delay is eventually overcome to allow the continuation of development and the formation of fruiting bodies.

\section{DISCUSSION}

Prior to this study of Dictyostelium MPP, there was no information on $\alpha$-MPP in the Dictyostelium Database. The present study focused on characterizing $\alpha$-MPP and $m p p A$, the gene encoding $\alpha$-MPP. The Dictyostelium genome has a single copy of mppA (data not shown), and the Dictyostelium genome project revealed that the gene encoding $\alpha$-MPP (DDB0232199, mppA) is located on chromosome 2 (http://dictybase.org) (Eichinger et al., 2005).

As shown in Figs 3 and 4(a), expression of $\alpha$-MPP mRNA is downregulated after early development, whereas, on the whole, its protein is expressed at a constant level as two forms, $\alpha-\mathrm{MPP}_{\mathrm{H}}$ and $\alpha-\mathrm{MPP}_{\mathrm{L}}$, throughout the life cycle, except at $12 \mathrm{~h}$ of development. Expression patterns of $\alpha$ MPP mRNA and its protein during development are similar to those of some other mitochondrial proteins, such as $\beta$-MPP (Nagayama et al., 2008), succinyl-CoA synthetase $\alpha$-subunit (Birney \& Klein, 1995), adenine nucleotide translocator (Bof et al., 1999), chaperonin 60 (Kotsifas et al., 2002) and DNA topoisomerase (Komori et al., 1997), suggesting the stable nature of mitochondrial proteins in Dictyostelium development.

Western blot analysis using an anti- $\alpha$-MPP antiserum, which recognizes the C-terminal region (amino acid residues 238654 ) of $\alpha$-MPP, showed two major cross-reactivity bands, $\alpha$ -
$\operatorname{MPP}_{\mathrm{H}}(65 \mathrm{kDa})$ and $\alpha-\mathrm{MPP}_{\mathrm{L}}(60 \mathrm{kDa})$. These two forms might be produced from the $m p p A$ gene, which is a single copy in the Dictyostelium genome, by alternative splicing. However, the fact that the mppA gene has no apparent intron and that, in Fig. 7, $\alpha-\mathrm{MPP}_{\mathrm{L}}$ appears to be produced by processing of $\alpha-\mathrm{MPP}_{\mathrm{H}}$ indicates that $\alpha-\mathrm{MPP}_{\mathrm{H}}$ and $\alpha$ $\mathrm{MPP}_{\mathrm{L}}$ are not the products of a single-copy $m p p A$ gene produced by alternative splicing.

$\alpha-\mathrm{MPP}_{\mathrm{H}}$ and $\alpha-\mathrm{MPP}_{\mathrm{L}}$ are present in the mitochondrial matrix fraction (Nagayama et al., 2008). Since $\alpha-M P P_{H}$ is smaller than the predicted size of the precursor form, $73 \mathrm{kDa}$, it is considered that $\alpha-\mathrm{MPP}_{\mathrm{H}}$ is an intermediate. $\alpha$ $\mathrm{MPP}_{\mathrm{L}}$ appears to be the mature form of $\alpha$-MPP, because MPP activity is lost when $\alpha-\mathrm{MPP}_{\mathrm{L}}$ is absent in the cells (Figs 4, 6 and 9). This is also supported by the results of expression of $\alpha \mathrm{MPP} 237-\mathrm{GST}$ in D. discoideum and in E. coli (Fig. 5).

Since the expression pattern of $\alpha-\mathrm{MPP}_{\mathrm{H}}$ processing activity during development is similar to that of MPP activity (Figs 4, 7 and 9), it is possible that the processing activity is due to the self-processing of MPP. Some modification of $\alpha-\mathrm{MPP}_{\mathrm{H}}$, such as phosphorylation/dephosphorylation or glycosylation/deglycosylation, might activate its self-processing. When the MPP activity and $\alpha-\mathrm{MPP}_{\mathrm{L}}$ disappeared at the slug stage, another form, which was slightly smaller than $\alpha-\mathrm{MPP}_{\mathrm{H}}$, was detected (Fig. 6). The appearance of this form might reflect differences in the phosphorylated and/ or glycosylated state of the $\alpha$-MPP molecule species. At present, however, we have no information on this form. There was a considerable difference in kinetics of the processing activities using COX IV precursor and $\alpha-\mathrm{MPP}_{\mathrm{H}}$ as substrates, when the activities were measured at low temperatures such as 0 or $4{ }^{\circ} \mathrm{C}$. The COX IV precursor was 
processed to intermediate within $1 \mathrm{~min}$, while $\alpha-\mathrm{MPP}_{\mathrm{H}}$ processing activity was not detectable after $1 \mathrm{~h}$ incubation at these temperatures (data not shown). Since it is possible that MPP shows different kinetics on different substrates, the possibility of self-processing could not be excluded. Alternatively, $\alpha-\mathrm{MPP}_{\mathrm{H}}$ could be cleaved by an unidentified protease. Since an $\alpha$ MPP237-GST fusion protein containing only the N-terminal 237 residues of $\alpha$-MPP was also found to be expressed as two protein bands, this suggests that processing of $\alpha-\mathrm{MPP}_{\mathrm{H}}$ to $\alpha-\mathrm{MPP}_{\mathrm{L}}$ is unlikely to result from self-processing. If this is the case, MPP activity could be controlled by developmentally regulated expression or activation/inactivation of the unknown protease.

In the $\alpha \mathrm{A} 2$ strain, the effects of the $\alpha$-mpp antisense RNA were not observed in vegetatively growing cells and in cells during early development. The developmental phase of the slug stage, however, was prolonged. MPP enzyme activity was not detected during the prolonged period of the slug stage (Fig. 9b). The accumulation of $\alpha-\mathrm{MPP}_{\mathrm{H}}$ at the slug stage of the $\alpha \mathrm{A} 2$ strain appears to be caused by the absence of $\alpha-\mathrm{MPP}_{\mathrm{H}}$ processing activity (Fig. 9a, c); that is, the defect in $\alpha-\mathrm{MPP}_{\mathrm{H}}$ processing activity and repression of the re-expression of $\alpha-\mathrm{MPP}_{\mathrm{L}}$ and MPP activity at the slug stage resulted in a prolonged slug stage (Figs 8 and 9). These results indicate that the re-expression (or reactivation) of $\alpha-\mathrm{MPP}_{\mathrm{H}}$ processing activity at the late slug stage appears to be necessary for the formation of a fruiting body.

Defective mitochondria resulting from mutation of the mitochondrial genome cause defects in cell-type differentiation, a prolonged slug stage, and a failure to form fruiting bodies (Wilczynska et al., 1997; Chida et al., 2004, 2008). Also, deficiencies in nuclear-encoded mitochondrial proteins cause defects in Dictyostelium development (van Es et al., 2001; Kotsifas et al., 2002; Morita et al., 2005). Especially, mitochondrial chaperone Hsp90 (TRAP-1) has been shown to be involved in late development, including spore differentiation (Morita et al., 2005). Mitochondrial defects caused by a decrease of MPP activity by $\alpha-m p p$ antisense RNA inhibition may prolong the slug stage to delay late development. Despite this similar phenotype, the relationship between DdTRAP- 1 and $\alpha$-MPP remains to be determined. Taken together, however, these studies highlight the importance of mitochondrial function in Dictyostelium development.

Although antisense RNA of the $m p p A$ gene resulted in a fairly weak inhibition of $\alpha$-MPP expression in vegetative cells (Nagayama et al., 2008), there was no effect during early development (up to $\sim 10 \mathrm{~h}$ ), when the $\alpha$-MPP mRNA is strongly expressed. After $10 \mathrm{~h}$ of development, transcription of the $m p p A$ gene is downregulated to less than one-tenth of that in vegetative cells (Fig. 3). Although the reason why the repression of $m p p A$ resulted in such a prolonged slug stage is largely unknown, it is possible that the rather weak repression has greater effects at the slug stage, where the mRNA level of $\alpha$-MPP is much lower than that in vegetatively growing cells. The expression of $\alpha-m p p$ antisense RNA was controlled by an actin 6 promoter. Actin genes are highly expressed during growing phases and early development (Alton \& Lodish, 1977; Margolskee \& Lodish, 1980). Since expression of actin genes decreases during late development, expression of $\alpha-m p p$ antisense RNA might also decrease during culmination. As a result, after the prolonged slug stage, culmination might start to give rise to formation of a fruiting body.

In this report, we show that a novel mechanism controls MPP activity via the processing of $\alpha$-MPP by an unidentified protease activity in Dictyostelium. Although much research on MPP of other organisms has been reported, there has been no report, to our knowledge, that MPP activity is controlled by the processing of the constituent subunit, $\alpha$-MPP or $\beta$-MPP. So, the MPP activity-controlling mechanism via the processing of $\alpha$-MPP might be specific to Dictyostelium. At present, however, the mechanism underlying the processing of $\alpha-\mathrm{MPP}_{\mathrm{H}}$ to $\alpha-\mathrm{MPP}_{\mathrm{L}}$ has not been fully elucidated. To determine the processing mechanism of $\alpha$-MPP and the controlling mechanism of MPP activity, the purification and characterization of the unidentified protease necessary for the processing of $\alpha-M P P_{H}$ to $\alpha-M P P_{L}$ and the identification of the N-terminal residues of $\alpha-\mathrm{MPP}_{\mathrm{H}}$ and $\alpha-\mathrm{MPP}_{\mathrm{L}}$ are in progress.

\section{ACKNOWLEDGEMENTS}

We are very grateful to Dr C. Thompson (Manchester University, UK) and Dr H. L. Ennis (Columbia University, USA) for critical reading of the manuscript and helpful comments, and to $\mathrm{Dr} \mathrm{H}$. Ochiai (CRIS, Hokkaido University, Japan) for helpful comments. We also thank the Dictyostelium cDNA project group for the cDNA sequence (contig U10434-1) and for the plasmid VSK 134 containing the full-length COX IV cDNA. This work was done, in part, at the Gene Research Center of Hirosaki University.

\section{REFERENCES}

Alton, T. H. \& Lodish, H. F. (1977). Developmental changes in messenger RNAs and protein synthesis in Dictyostelium discoideum. Dev Biol 60, 180-206.

Ashworth, J. M., Duncan, D. \& Rowe, A. J. (1969). Changes in fine structure during cell differentiation of the cellular slime mould Dictyostelium discoideum. Exp Cell Res 58, 73-78.

Birney, M. A. \& Klein, C. (1995). Cloning and expression of the $\alpha$ subunit of succinyl-CoA synthetase from Dictyostelium discoideum. Arch Biochem Biophys 319, 93-101.

Bof, M., Brandolin, G., Satre, M. \& Klein, G. (1999). The mitochondrial adenine nucleotide translocator from Dictyostelium discoideum: functional characterization and DNA sequencing. Eur $J$ Biochem 259, 795-800.

Bokko, P. B., Francione, L., Bandala-Sanchez, E., Ahmed, A. U., Annesley, S. J., Huang, X., Khurana, T., Kimmel, A. R. \& Fisher, P. R. (2007). Diverse cytopathologies in mitochondrial disease are caused 
by AMP-activated protein kinase signaling. Mol Biol Cell 18, $1874-$ 1886.

Branda, S. S. \& Isaya, G. (1995). Prediction and identification of new natural substrates of the yeast mitochondrial intermediate peptidase. J Biol Chem 270, 27366-27373.

Chida, J., Yamaguchi, H., Amagai, A. \& Maeda, Y. (2004). The necessity of mitochondrial genome DNA for normal development of Dictyostelium cells. J Cell Sci 117, 3141-3152.

Chida, J., Amagai, A., Tanaka, M. \& Maeda, Y. (2008). Establishment of a new method for precisely determining the functions of individual mitochondrial genes, using Dictyostelium cells. BMC Genet 9, 25.

Cotter, D. A., Miura-Santo, L. Y. \& Hohl, H. R. (1969). Ultrastructural changes during germination of Dictyostelium discoideum spores. J Bacteriol 100, 1020-1026.

Early, A., McRobbie, S. J., Duffy, K. T., Jermyn, K. A., Tilly, R., Ceccarelli, A. \& Williams, J. G. (1988). Structural and functional characterization of genes encoding Dictyostelium prestalk and prespore cell-specific proteins. Dev Genet 9, 383-402.

Eichinger, L., Pachebat, J. A., Glockner, G., Rajandream, M. A., Sucgang, R., Berriman, M., Song, J., Olsen, R., Szafranski, K. \& other authors (2005). The genome of the social amoeba Dictyostelium discoideum. Nature 435, 43-57.

Fisher, P. R. \& Annesley, S. J. (2006). Slug phototaxis, thermotaxis, and spontaneous turning behavior. Methods Mol Biol 346, 137-170.

Foury, F., Roganti, T., Lecrenier, N. \& Purnelle, B. (1998). The complete sequence of the mitochondrial genome of Saccharomyces cerevisiae. FEBS Lett 440, 325-331.

Gakh, O., Cavadini, P. \& Isaya, G. (2002). Mitochondrial processing peptidases. Biochim Biophys Acta 1592, 63-77.

Gavel, Y. \& von Heijne, G. (1990). Cleavage-site motifs in mitochondrial targeting peptides. Protein Eng 4, 33-37.

George, R. P., Hohl, H. R. \& Raper, K. B. (1972). Ultrastructural development of stalk-producing cells in Dictyostelium discoideum, a cellular slime mould. J Gen Microbiol 70, 477-489.

Hendrick, J. P., Hodge, P. E. \& Rosenberg, L. E. (1989). Survey of amino-terminal proteolytic cleavage sites in mitochondrial precursor proteins: leader peptides cleaved by two matrix proteases share a three-amino acid motif. Proc Natl Acad Sci U S A 86, 4056-4060.

Howard, P. K., Aher, K. G. \& Firtel, R. A. (1988). Establishment of a transient expression system for Dictyostelium discoideum. Nucleic Acids Res 16, 2613-2623.

Inazu, Y., Chae, S. C. \& Maeda, Y. (1999). Transient expression of a mitochondrial gene cluster including rps4 is essential for the phaseshift of Dictyostelium cells from growth to differentiation. Dev Genet 25, 339-352.

Ito, A. (1999). Mitochondrial processing peptidase: multiple-site recognition of precursor proteins. Biochem Biophys Res Commun 265, 611-616.

Kitada, S., Shimokata, K., Niidome, T., Ogishima, T. \& Ito, A. (1995). A putative metal-binding site in the $\beta$-subunit of rat mitochondrial processing peptidase is essential for its catalytic activity. J Biochem 117, 1148-1150.

Kitada, S., Kojima, K., Shimokata, K., Ogishima, T. \& Ito, A. (1998). Glutamate residues required for substrate binding and cleavage activity in mitochondrial processing. J Biol Chem 273, 32547-32553.

Koehler, C. M. (2004). New developments in mitochondrial assembly. Annu Rev Cell Dev Biol 20, 309-335.

Kojima, K., Kitada, S., Shimokata, K., Ogishima, T. \& Ito, A. (1998). Cooperative formation of a substrate binding pocket by $\alpha$ - and $\beta$ subunits of mitochondrial processing peptidase. J Biol Chem 273, 32542-32546.
Komori, K., Kuroe, K., Yanagisawa, K. \& Tanaka, Y. (1997). Cloning and characterization of the gene encoding a mitochondrially localized DNA topoisomerase II in Dictyostelium discoideum. Biochim Biophys Acta 1352, 63-72.

Kotsifas, M., Barth, C., Lozanne, A. D., Lay, S. T. \& Fisher, P. R. (2002). Chaperonin 60 and mitochondrial disease in Dictyostelium. J Muscle Res Cell Motil 23, 839-852.

Lill, R. \& Kispal, G. (2000). Maturation of cellular Fe-S proteins: an essential function of mitochondria. Trends Biochem Sci 25, 352356.

Lowry, O. H., Rosebrough, N. J., Farr, A. L. \& Randall, R. J. (1951). Protein measurement with the folin phenol reagent. J Biol Chem 193, 265-275.

Luciano, P., Geoffroy, S., Brandel, A., Hermandez, J.-F. \& Geli, V. (1997). Functional cooperation of the mitochondrial processing peptidase subunits. J Mol Biol 272, 213-225.

Luciano, P., Tokatlidis, K., Chambre, I., Germanique, J.-C. \& Geli, V. (1998). The mitochondrial processing peptidase behaves as a zincmetallopeptidase. J Mol Biol 280, 193-199.

Maarse, A. C., Van Loon, A. P., Riezman, H., Gregor, I., Schatz, G. \& Grivell, L. A. (1984). Subunit IV of yeast cytochrome $c$ oxidase: cloning and nucleotide sequencing of the gene and partial amino acid sequencing of the mature protein. EMBO J 3, 28312837.

Maeda, Y. (1971). Formation of a prespore specific structure from a mitochondrion during development of the cellular slime mold, Dictyostelium discoideum. Dev Growth Differ 13, 211-219.

Margolskee, J. P. \& Lodish, H. F. (1980). The regulation of the synthesis of actin and two other proteins induced early in Dictyostelium discoideum development. Dev Biol 74, 50-64.

Morita, T., Amagai, A. \& Maeda, Y. (2005). Involvement of the TRAP-1 homologue, Dd-TRAP1, in spore differentiation during Dictyostelium development. Exp Cell Res 303, 425-431.

Nagao, Y., Kitada, S., Kojima, K., Toh, H., Kuhara, S., Ogishima, T. \& Ito, A. (2000). Glycine-rich region of mitochondrial processing peptidase $\alpha$-subunit is essential for binding and cleavage of the precursor proteins. J Biol Chem 275, 34552-34556.

Nagayama, K., Itono, S., Yoshida, T., Ishiguro, S., Ochiai, H. \& Ohmachi, T. (2008). Antisense RNA inhibition of the $\beta$ subunit of the Dictyostelium discoideum mitochondrial processing peptidase induces the expression of mitochondrial proteins. Biosci Biotechnol Biochem 72, 1836-1846.

Newell, P. C., Telser, A. \& Sussman, M. (1969). Alternative developmental pathways determined by environmental conditions in the cellular slime mold Dictyostelium discoideum. J Bacteriol 100, 763-768.

Newmeyer, D. D. \& Ferguson-Miller, S. (2003). Mitochondria: releasing power for life and unleashing the machineries of death. Cell 112, 481-490.

Scarpulla, R. C. (2006). Nuclear control of respiratory gene expression in mammalian cells. J Cell Biochem 97, 673-683.

Shimokata, K., Kitada, S., Ogishima, T. \& Ito, A. (1998). Role of $\alpha$ subunit of mitochondrial processing peptidase in subunit recognition. J Biol Chem 273, 25158-25163.

Sussman, R. \& Sussman, M. (1967). Cultivation of Dictyostelium discoideum in axenic medium. Biochem Biophys Res Commun 29, 5355.

van Es, S., Wessels, D., Soll, D. R., Borleis, J. \& Devreotes, P. N. (2001). Tortoise, a novel mitochondrial protein, is required for directional responses of Dictyostelium in chemotactic gradients. J Cell Biol 152, 621-632. 
von Heijne, G. (1990). The signal peptide. J Membr Biol 115, 195201.

von Heijne, G., Steppuhn, J. \& Herrmann, R. G. (1989). Domain structure of mitochondrial and chloroplast targeting peptides. Eur $J$ Biochem 180, 535-545.
Wilczynska, Z., Barth, C. \& Fisher, P. R. (1997). Mitochondrial mutations impair signal transduction in Dictyostelium discoideum slugs. Biochem Biophys Res Commun 234, 39-43.

Edited by: N. L. Glass 